\title{
Preliminary Geologic and Engineering Assessment of the Pyroclastic Deposits in the Central Part of Harrat Rahat
}

\author{
M. R. Moufti, A.A. Sabtan, O.R. El-Mahdy and W.M. Shehata \\ Faculty of Earth Sciences, King Abdulaziz University, \\ Jeddah, Saudi Arabia
}

Received: 22/2/99 Revised: 15/12/99 Accepted: 6/3/2000

\begin{abstract}
Cenozoic volcanic rocks cover vast areas in the Arabian Shield consisting mainly of lava flows associated with pyroclastic deposits namely scoria and cinders. Markets for pyroclastics include aggregate for road construction and surfacing, lightweight concrete and light weight-heat-insulating building blocks. These pyroclastic deposits are also the main source for the natural pozzolanic material in the Kingdom. The purpose of this investigation is to survey the central part of Harrat Rahat and locate the most suitable sources of these deposits. A reconnaissance survey was performed on over thirty volcanic cones in the specified area and four cinder cones that seem to have suitable scoria deposits both from the economic and engineering points of views, were selected.
\end{abstract}

The preliminary investigations on these sites suggest that Jabal Halat ash Shaykh show the best scoria occurrence in the investigated area. Jabal Al Hala and Jabal as Sahiliyah have suitable quantities of scoria while Jabal Suwah has limited scoria resources. The geology and geomorphology of the four sites are presented in this work. Some geological and geomorphological observations during this survey may help in identifying other craters that may make good sources of scoria deposits in other areas. Results of preliminary laboratory investigations indicate that the material could be economically utilized as lightweight aggregate, cement additive and as heat insulating material. The measured parameters are compared with the specifications required by the ASTM and other designations. The results of the strength activity index and alkali silica reaction tests were not encouraging, due to a technical problem, and the tests will be repeated on 
finer material. Detailed economic and engineering investigations of the scoria deposits and concrete mixes made out of these materials are now in progress.

\section{Introduction}

Several Cenozoic lava fields, of ages ranging from 30 Ma to Recent, are widely exposed in western Saudi Arabia. They are composed mainly of large expanses of successive basaltic flows covering an area of approximately $100,000 \mathrm{~km}^{2}$. These fields, locally known as harrats, form spectacular volcanic landforms along the eastern shore of the Red Sea. The other major volcanic landforms present in the harrats are the basaltic scoria or cinder cones. These cones which form in some harrats distinctive alignments, are chiefly the result of strombolian eruptions. The scoria cones are largely composed of basaltic fragments ranging in size from ash to large clinkery cinders and arranged in beds forming the slopes of the cones. The most abundant pyroclastic deposits in the harrats are the basaltic scoria. Although these deposits are generally denser than the pumice, they have a good market as aggregate for road construction, for the manufacturing of light weight and heat insulated building blocks and as an additive in the cement industry.

Brown et al. (1963 a \& b), mapped the harrats in the Arabian Shield as undifferentiated units which were later given ages by Brown (1972) ranging from Oligocene to Holocene. Since that date, several investigations were performed on the individual harrats including Harrat Rahat. Camp and Roobol (1987 and 1989), mapped the geology and studied the evolution of Harrat Rahat. They estimated ages to the volcanic eruptions ranging from few hundreds to few millions years. More recently, Roobol et al. (1998a; 1998b and 1999) performed reconnaissance helicopter surveys of Al Madinah area, central Harrat Rahat and Harrat Kishb to evaluate the basalt as industrial rock. However, relatively small amounts of lab work were done in these studies and only little overlap is encountered with this investigation.

The first recommendation on the beneficiation studies of industrial minerals in the Kingdom was made by Benedetto and Baudet (1975) who gave a list of occurrences that warrant further investigations. Laurent and Al-Nakhebi (1979), examined more than 150 pyroclastic cones in the different Harrats including Harrat Rahat for potential pozzolanic material. Marked pozzolanic activity was revealed in scoriacous samples from Harrat Al-Hutaymah but the results from Harrat Rahat were average. They recommended further work to be done. Laurent and Chevrel (1980), studied Harrat Lunayyir and indicated the presence of many pyroclastic cones that display materials suitable as lightweight aggregate. Odent and Roger (1980), displayed the same findings for the Harrats in Al Birk 
area. They also showed few cones that contain scoria cinder with pozzolanic activity in the same area.

The investigations for industrial rocks in Harrat Rahat started in 1985 when Al-Nakhebi and Laurent prospected an area of $900 \mathrm{~km}^{2}$. Their investigation revealed that 16 out of 34 investigated cones contain materials with suitable pozzolanic properties and 5 samples of loose scoria display a dry unit weight favorable for use as light weight aggregate. Watts et al. (1992 a \& b), prepared a review report on behalf of the DGMR that includes the evaluation of the extent, status and adequacy of the lava fields including Harrat Rahat for their economic deposits of light weight aggregates and pozzolans. An atlas of industrial minerals in Saudi Arabia was prepared by Laurent et al. (1993) and published by the DGMR includes a brief account on the pozzolan and light weight aggregate occurrences in the Shield.

The purpose of this work is to survey the central part of Harrat Rahat and locate the most suitable occurrences of scoria that can be used for light weight concrete, light weight-heat-insulating building blocks and pozzolanic additive to Portland cement. An exploration route (Fig. 1) was selected in such a way that it passes by almost all the cones present in the area of study (approximately 30 cones) where 4 cones were found to have sufficient quantities of suitable materials to warrant detailed investigations and possible economic exploitation. These investigations included geological and geomorphological mapping, petrographic studies and testing for the physical, chemical, mechanical and thermal conductivity properties of the materials.

\section{Criteria for Cone Selection}

The following criteria were adhered to in selecting the four cones that were found suitable for the detailed investigations:

1. The volume of the deposit is sufficiently large to warrant economic exploitation.

2. The average specific gravity of the scoria deposits confirms with ASTM standards for lightweight aggregate.

3. The scoria material is either free of alterations or slightly altered.

4. The scoria material is essentially devoid of heavier foreign inclusions and impurities.

5. Previous investigations suggest that the materials have pozzolanic activity.

6. The deposits are either exposed on the surface or are covered by a reasonably thin overburden.

7. The general geomorphic features of the area provide suitable conditions for easy excavation and processing of the deposits. 
8. The cone is located within reach of the main highway and is accessed by reasonably well maintained gravel road.

Based on these criteria four cones were found to be suitable for further detailed investigations. These cones are Jabal Halat ash Shaykh, Jabal Al Hala, Jabal Suwah and Jabal as Sahiliyah (Fig. 1). The exploitation of scoria from Jabal

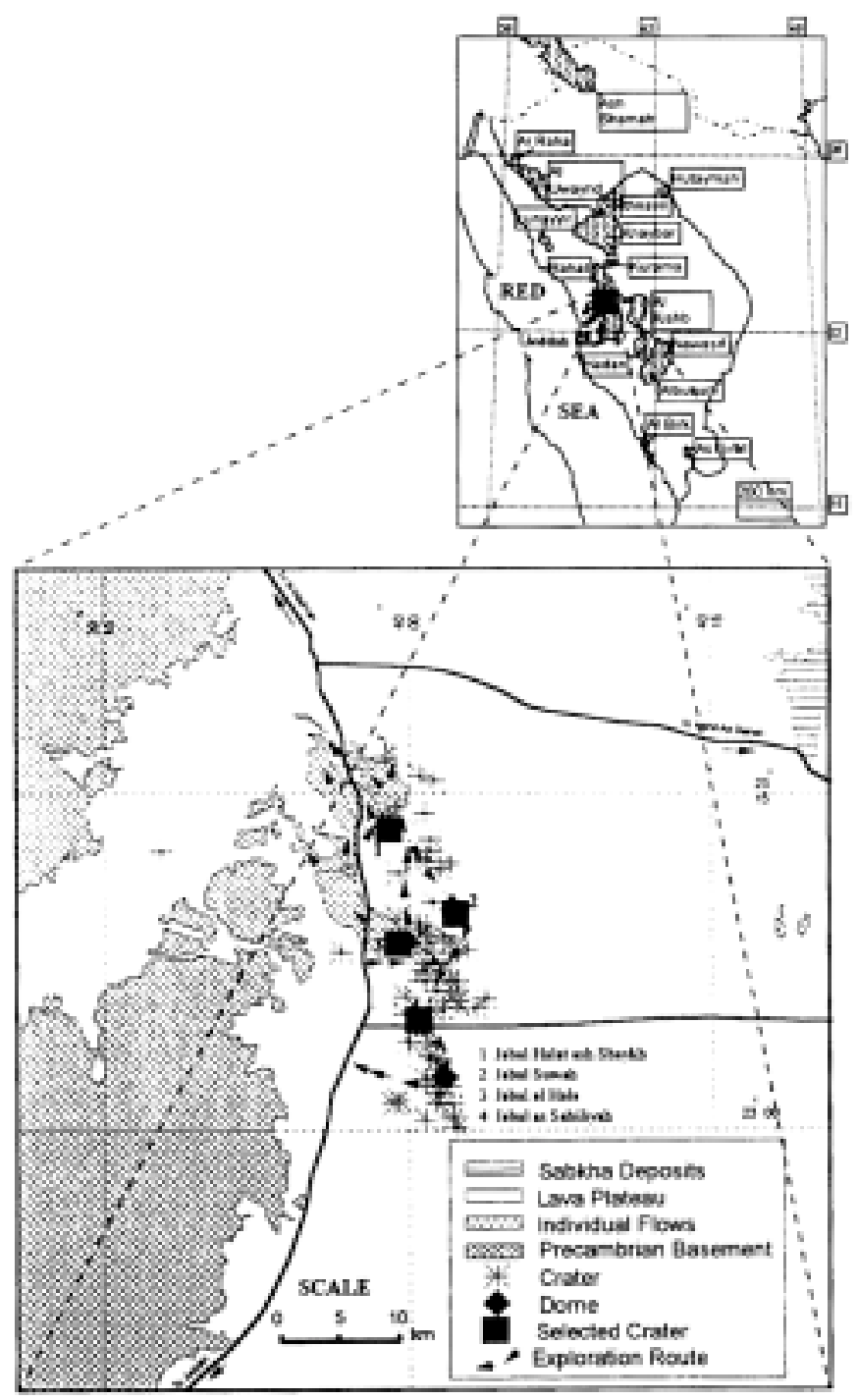

FIG. 1. Index map showing the location of the studied area, exploration route and investigated cones. 
Halat ash Shaykh cone is undergoing, at the present time, by the Commercial Investment Corporation (C.I.C.). The cone is reinvestigated in this research with C.I.C. permission.

Other interesting criteria were also observed during the course of this investigation and can be used as guides for future exploration in both Harrat Rahat and the other harrats. These criteria are:

1. The cone should be young enough that the scoria deposits were not subjected to long period of erosion. The relative age of the cone can be extrapolated from the ratio of the cone height to its width. Higher and large diameter cones are more likely to contain suitable amount of scoria deposits. Fig. 2 shows the relationship between the height and diameter of the cones present in the investigated area. It is clear that the four selected cones cluster in the area of the maximum height and maximum diameter.

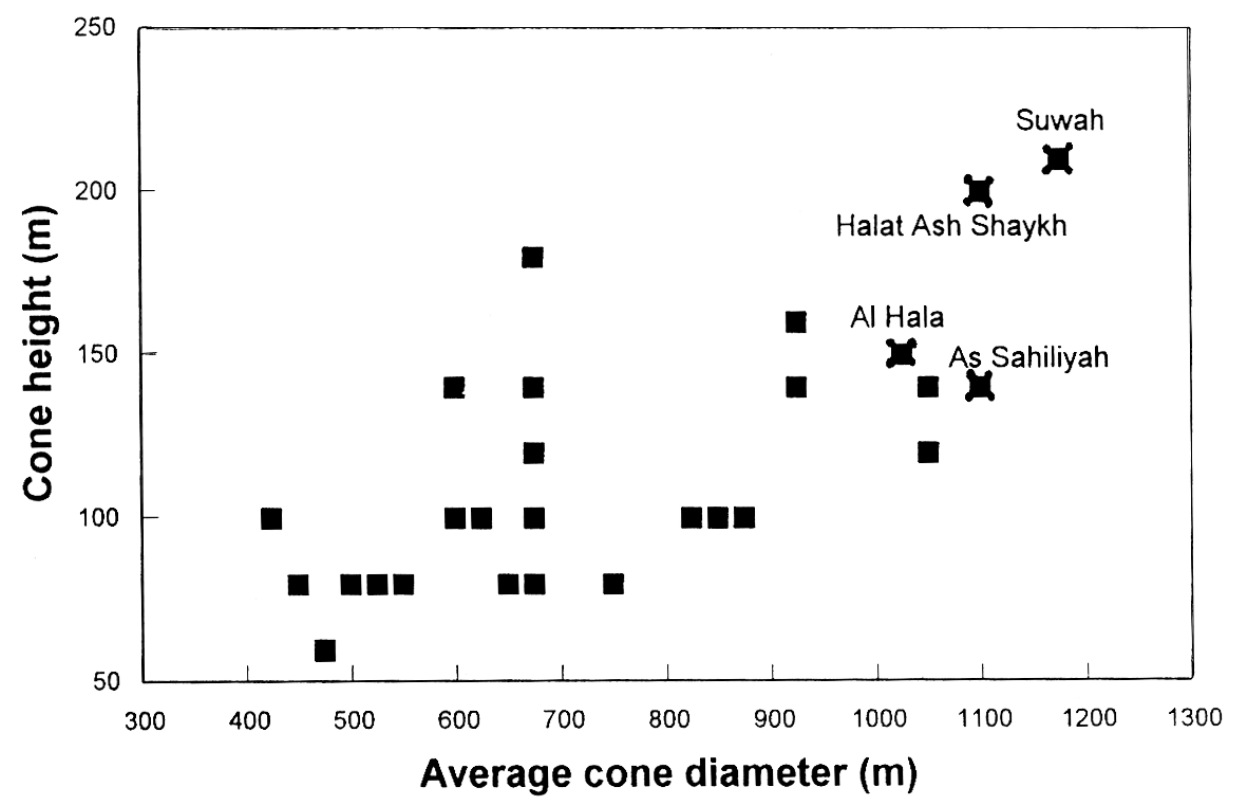

FIG. 2. Relationship between height and diameter of volcanic cones at the studied area.

2. The cone should be constrained and surrounded by higher topography in order also to prevent the scoria deposited around the cone from erosion and spreading in larger area. It happened that the prevailing wind direction during the eruption of the studied cones in Harrat Rahat was from the west-southwest, southwest and south-southwest directions. This fact caused the main scoria deposits to be present in the northeastern side of the cones. Jabal Halat ash 
Shaykh, Jabal Al Hala and Jabal as Sahiliyah are constrained from the northeast side and consequently sufficient scoria deposits were encountered. However, the east and northeast sides of Jabal Suwah have relatively low and flat topography and also thin widespread occurrences of scoria deposits.

\section{Geomorphology and Geology}

The geomorphology and the geology of the four selected cones was mapped at scale of 1:20 000 with the aid of the aerial photographs and using an enlarged topographic contour map as a base map.

\section{Geomorphology and Geology of Jabal Halat ash Shaykh}

Jabal Halat ash Shaykh is a volcanic cone formed in some sections by alternating layers of basalt and scoria. It is approximately $200 \mathrm{~m}$ in height and is breached from the west side by a lava flow to the west, northwest and southwest (Fig. 3a). The erosion stage is not as severe as some other cones in the area which indicates that Jabal Halat ash Shaykh is relatively young in age. The crater of the cone is $500 \mathrm{~m}$ in diameter and is intersected by an east-west trending ridge formed by lava erupted through an old fissure. The southern slopes are intersected by several ill-developed consequent streams through which debris avalanches take place forming the talus material at the foot of the cone. A major block glide exists on the northern slopes leaving a tension crack that was widened and deepened by floodwater.

The geological units observed at Jabal Halat ash Shaykh are mainly different types of volcanic ejecta and flows. These units are scoriaceous basalt, red agglutinated spatter, black scoria, yellow cemented lapilli, old subdued basalt flow, old basalt flow and young basalt flow (Fig. 3b). The black scoria which is the material of interest in this research is pitch black or grayish black in color, vesicular and light in weight. The unit is often well bedded with occasional graded bedding, fine lamination or no bedding. The fragment are mostly angular to subangular and have a maximum of $2 \mathrm{~cm}$ in diameter. Volcanic bombs of various sizes $(10-50 \mathrm{~cm})$ are often loosely scattered within the black scoria layers. The black scoria covers the eastern and northeastern flanks of Jabal Halat ash Shaykh and is usually overlain by a thin veneer of reworked overburden.

\section{Geomorphology and Geology of Jabal Al Hala}

Jabal Al Hala is a volcanic cone consisting in some sections of alternating layers of basalt and scoria deposits with its western part covered mainly by red spatter agglutinate. It is breached from the west side and surrounded by different basaltic flows of different ages (Fig. 4a). A relatively younger flow exists on the older flows in the southeastern corner forming a low elevated mesa. Similar 


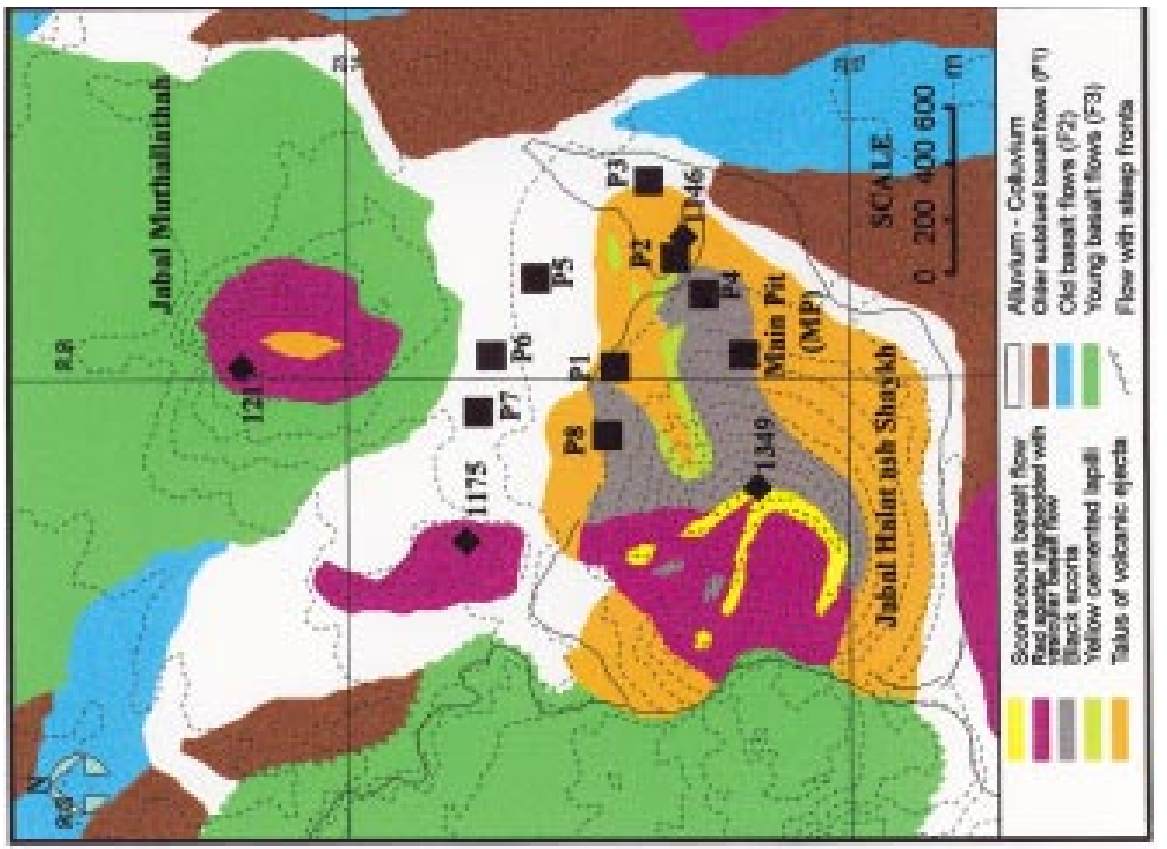

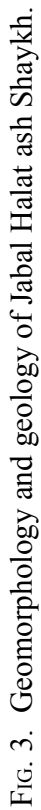

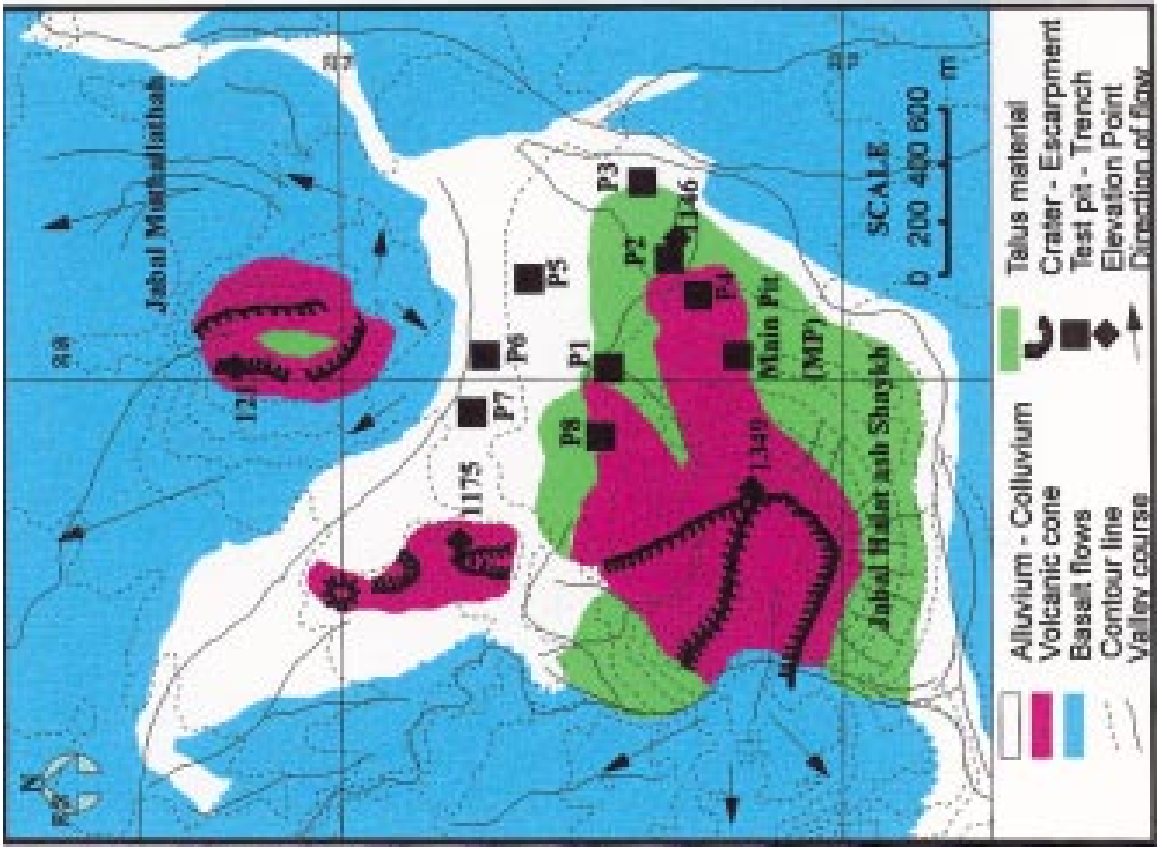



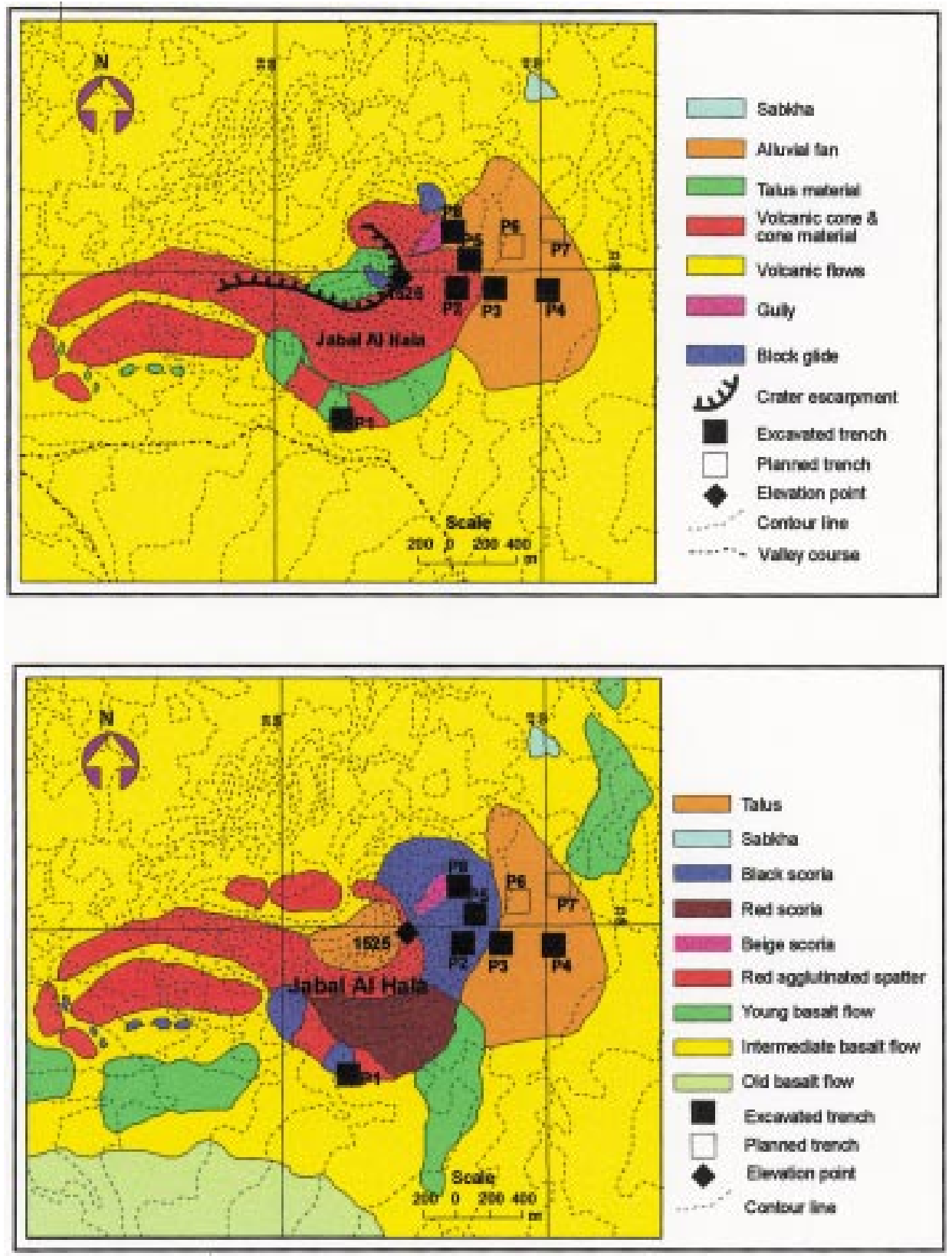

FIG. 4. Geomorphology and geology of Jabal Al Hala. 
to Jabal Halat ash Shaykh, the erosion stage is not as severe as some other surrounding cones. The cone is approximately $150 \mathrm{~m}$ in height and its crater is 400 $\mathrm{m}$ in diameter. The southern slopes were subjected to block glides forming talus material at the foot of the cone and leaving remains of the sliding beds at the top of the cone. The southern slopes also show recent solifluction movement of the black scoria deposits. The northeastern slopes are highly eroded by a radial stream to form a deep gully exposing the beige colored scoria beds.

The geological units recognized at Jabal Al Hala include different types of volcanic flows and pyroclastic deposits (Fig. 4b). These are scoria deposits, red agglutinated spatter, old basalt flow, intermediate basalt flow and young basalt flow. The scoria deposits are subdivided into three types according to their color; black, beige and red scoria. The bulk of the black scoria occurs at the northeastern slopes in addition to several small isolated mounds at the southern outskirts of the cone. The other two types of scoria (beige and red) are less abundant and delineated at the southwestern and northeastern slopes. The scoria fragments are mostly angular to subangular and less than $2 \mathrm{~cm}$ in diameter. They are vesicular and light in weight. The scoria layers are generally well bedded and are occasionally normally graded, finely laminated or massive. Volcanic bombs are often sporadically scattered within the black scoria.

\section{Geomorphology and Geology of Jabal Suwah}

Jabal Suwah is a volcanic cone type formed by alternating layers of lava and pyroclastic deposits (Fig. 5a). It is approximately $210 \mathrm{~m}$ in height, $550 \mathrm{~m}$ in diameter and is not breached as the case of most of the cones in the area. Similar to Jabal Halat ash Shaykh and Jabal Al Hala the erosion stage in the cone is not as severe as some other cones in the area which indicate that Jabal Suwah is relatively young in age. The cone is symmetrical with steep slopes near the top and concave with a decrease in the slope downwards. Locally the slopes are intersected by several ill-developed radial streams through which debris avalanches take place forming a strip of talus material at the foot of the cone. In other parts of the slopes, no definite drainage pattern is observed and the masses are wasted on these slopes by solifluction without any restriction to stream courses. Floodwater carved two gullies on the eastern slopes with the development of two consequent streams having very steep banks and V-shaped cross section. The southernmost gully is huge with the material that has been eroded forming fan deposits extending to a distance of one kilometer to the northeast.

The rock units recognized at Jabal Suwah (Fig. 5b) include different types of basaltic flows that cover almost half of the mapped area and outcrops of pyroclastic deposits. Mappable lithologies, arranged according to their lithostratigraphic position from top to bottom, are as follows: black and red scoria; 


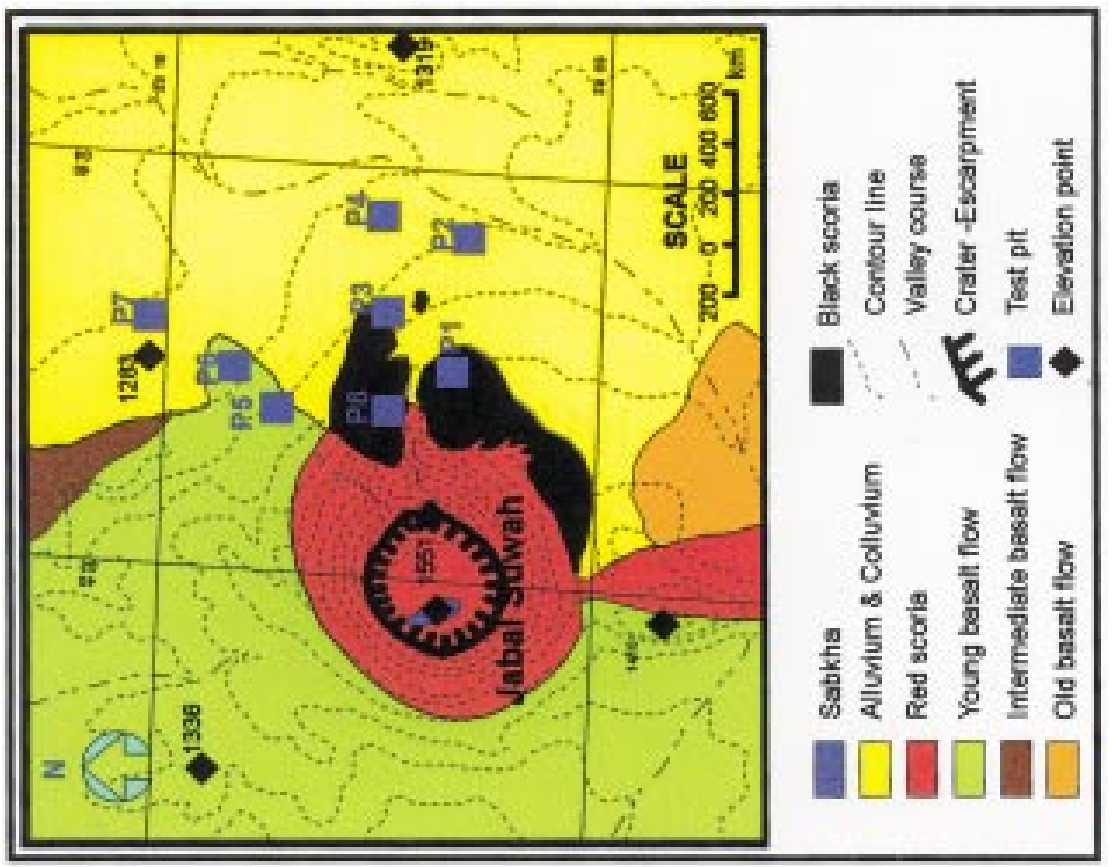

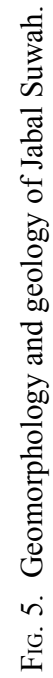
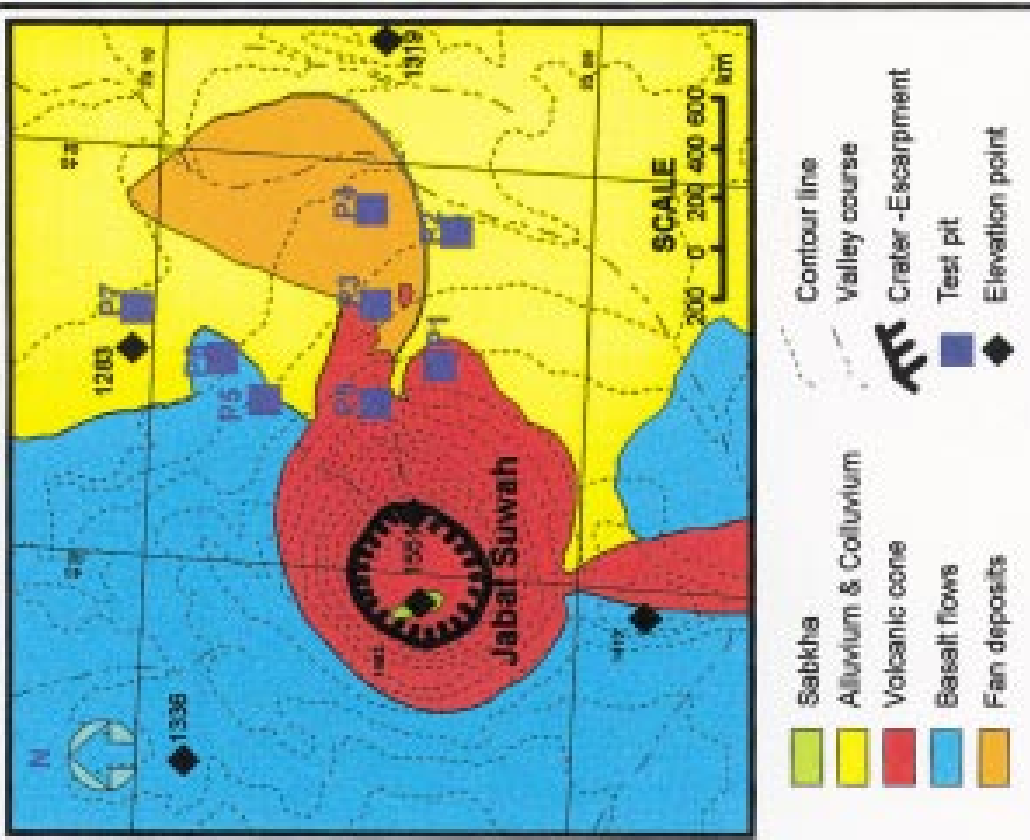
young, intermediate and old basalt flows. The bulk of the black scoria occurs at the eastern and southeastern slopes of Jabal Suwah cone, in addition to several small, oval-shaped isolated mounds at the eastern outskirts of the cone. Its subsurface extension has been defined in several of the trenches excavated in the area. The scoria grains are angular to subangular, less than $2 \mathrm{~cm}$ in diameter, highly vesicular and light in weight. Bedding is generally well developed with occasional normal graded bedding, finely laminated or massive. The red scoria constitutes the main body of the cone as well as the elongated ridge to the south of Jabal Suwah. It is commonly interbedded with scoriacous vesicular basalt bombs, beige lapilli tuffs, and red crystal lithic tuffs. The red scoria grains are angular, and are not as vesicular and lighter in density as the black scoria.

\section{Geomorphology and Geology of Jabal as Sahiliyah}

Jabal as Sahiliyah is a volcanic cone formed in some sections by alternating layers of red scoria and black scoria. The cone is associated with a smaller cone to the northeast of it. The main cone is approximately $130 \mathrm{~m}$ in height and is breached from the north-northwest while the small cone is $80 \mathrm{~m}$ high and is breached from the south (Fig. 6a). The erosion stage is moderate in the main cone and high in the small cone, which indicates that the main cone is relatively younger. The crater of the main cone is $500 \mathrm{~m}$ in diameter while the remnants of the crater of the small cone are approximately $200 \mathrm{~m}$ in diameter. The southern and northern slopes are intersected by several ill-developed consequent streams through which debris avalanches take place. A major block glide exists on the northern slopes mass wasting the red scoria.

The cones of Jabal as Sahiliyah (Fig. 6b) are composed of red scoria with subordinate black scoria. The bulk of the black scoria is located between the two cones in addition to two small oval mounds on the southern slopes of the main cone. The scoria is black to gray in color and the fragments are angular to subangular and are less than $2 \mathrm{~cm}$ in diameter. Bedding is well developed. Volcanic bombs of various sizes are commonly scattered within the black scoria. The black scoria is usually covered by a thin veneer of reworked material. The area surrounding the two cones is dominated by different types of basalt flows ranging from moderately to slightly vesicular and partly amygdaloidal to massive basalt. The youngest basalt is completely fresh and forms ridges while the oldest is moderately weathered and subdued.

\section{Aggregate Properties}

\section{Petrography}

The petrography of the aggregate includes the petrographic description of the aggregate particles under thin sections, the percentage of the material lost on ignition and the percentage of the clay lumps present in the aggregate. 


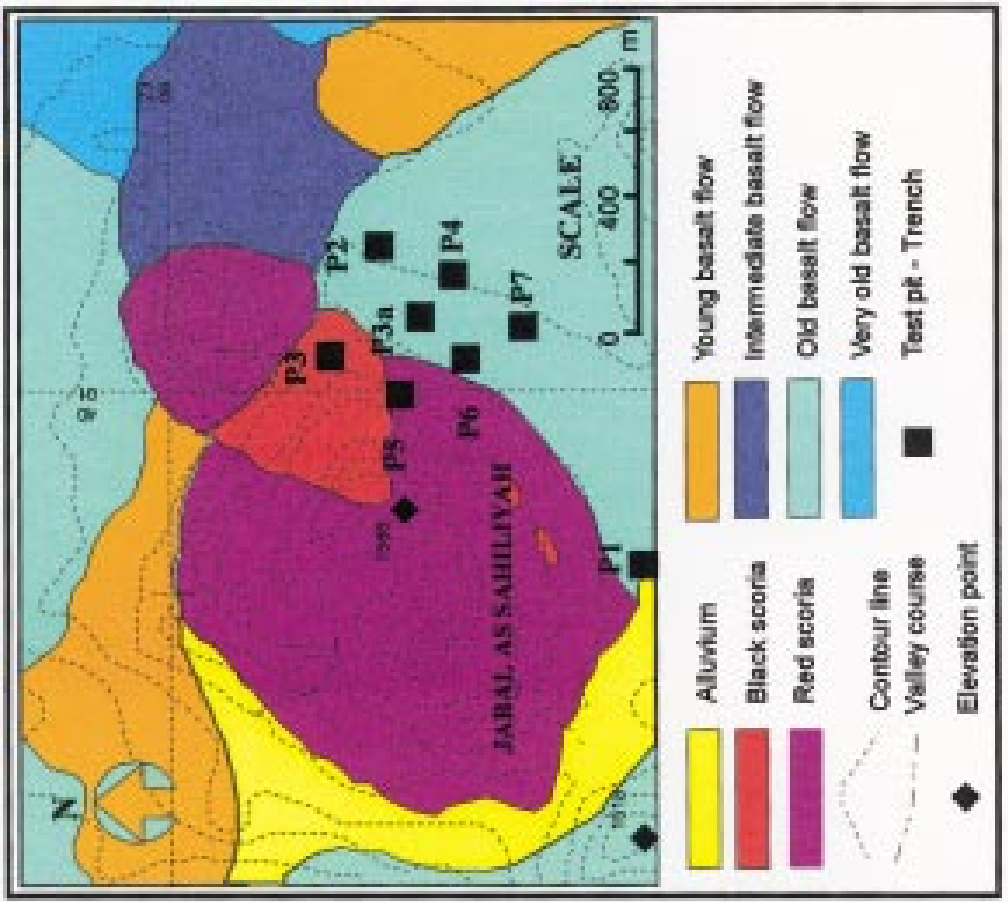

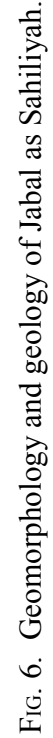


Several samples representing the aggregate from Jabal Halat ash Shaykh, Jabal Al Hala and Jabal Suwah were studied under the polarizing microscope. They, in general, show a similar mineralogical composition. The material is hemicrystalline with vesicular texture consisting of vesicles, glassy matrix and few crystals of clinopyroxene, plagioclase and olivine. The vesicles constitute more than $60 \%$ of the material. They show different shapes (rounded, subrounded, ovoid, lobate and sometimes irregular) but with limited size variations $(1 \mu \mathrm{m}-3 \mathrm{~mm}$ ) (Fig. 7). Some of the vesicles are connected while the others are isolated. The groundmass delineating the vesicles is made up of dark blackish volcanic glass containing abundant dusty iron oxides. In some altered samples, the vesicles are filled with or coated by secondary minerals such as carbonates, quartz and zeolites?) and brownish amorphous material. Some microlites of plagioclase and few crystals of clinopyroxenes or olivine are present. Accessory minerals are few and include apatite, magnetite and spinel.

Few samples were tested for their loss on ignition according to ASTM designation $\mathrm{C} 311$. The results show a range between $1.37 \%$ and $1.42 \%$ with an average of $1.41 \%$. This value is assumed to represent the total moisture and $\mathrm{CO}_{2}$ content in the scoria. The average value of the measured moisture content is $0.66 \%$. Therefore, the average $\mathrm{CO}_{2}$ lost by ignition is $0.75 \%$. The overall clay lumps content in the coarse aggregate was determined according to ASTM designation C142. In Jabal Halat ash Shaykh the percentage of the clay lumps ranges between 0 and $1.2 \%$ with an average of $0.6 \%$. In Jabal Al Hala, it ranges between 0.7 and $2.9 \%$ with an average of $1.5 \%$ while in Jabal Suwah it ranges between 1.5 and $1.8 \%$ with an average of $1.7 \%$. The clay lumps content at Jabal as Sahiliyah ranges between 0.8 and $2.2 \%$ with an average of $1.5 \%$. These values, most of the times, do not exceed the $2 \%$ maximum acceptable standard specification (ASTM Designation C 330) for lightweight aggregate for structural concrete. Table 1 and Fig. 8 gives the average clay lumps content for three different sizes of the scoria deposits.

\section{Material description}

The material description includes its color, surface texture, particle shape and angularity. The scoria in the four studied sites are more or less similar in their description. The main scoria body in Jabal Halat ash Shaykh, Jabal Al Hala and Jabal as Sahiliyah are pitch black to dark grey except for the altered layers which become brownish in color. Most of the scoria in Jabal Suwah and partly in Jabal Hala and Jabal as Sahiliyah are reddish or beige in color. The scoria particles are generally subrounded to angular and have rough to very rough surface texture. 


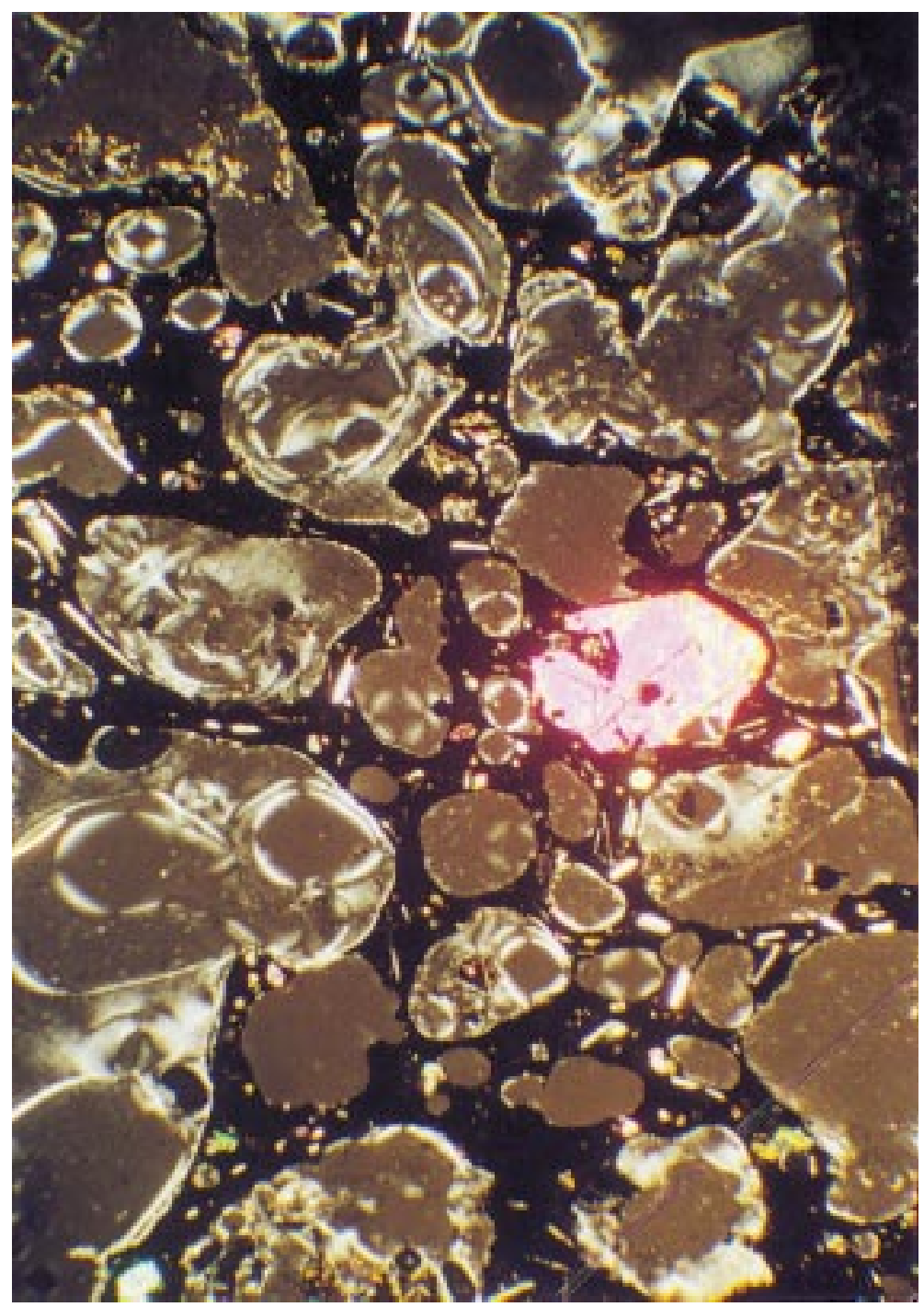

FIG. 7. Photomicrograph in a scoria sample showing the pore spaces, the glass groundmass and a phenocrysts of olivine.

\section{Physical properties}

The physical properties of the aggregate include the grain sizes, water absorption, materials finer than $75 \mu \mathrm{m}$, specific gravity and density. Tables 1 and Figs. 8 to 11 show the grain size distribution and average physical properties for the aggregate collected from the four sites.

The maximum size of the aggregate is mostly $19 \mathrm{~mm}$ (Fig. 9). The natural grading of the combined coarse and fine aggregate (Fig. 10), coarse aggregate 
or fine aggregate, however, do not conform with the grading requirements for light weight aggregate neither as structural concrete (ASTM C330), as concrete for masonry units (ASTM C331), nor as insulating concrete (ASTM C332). Further crushing is necessary in order to get the required grading. The material finer than $75 \mu \mathrm{m}$ ranges between 1.7 and $2.2 \%$ (Fig. 8). The bulk specific gravity of the coarse aggregate ranges between 1.46 and 1.74 while that of the fine aggregate ranges between 1.83 and 2.12 (Fig. 11). The average loose density for the combined fine and coarse aggregate, on the other hand (Fig. 11), is slightly higher than the 0.65 value required by ASTM Designations C 330, C 331 and C 332. The rodded density is slightly higher for all the tested samples.

TABLE 1. Physical properties of scoria samples collected from the four sites

\begin{tabular}{|c|c|c|c|c|}
\hline & $\begin{array}{c}\text { Jabal Halat ash } \\
\text { Shaykh }\end{array}$ & Jabal Al Hala & Jabal Suwah & Jabal as Sahiliyah \\
\hline $\begin{array}{l}\text { Maximum grain } \\
\text { size }(\mathrm{mm})\end{array}$ & 19 & 19 & 9.6 & 19 \\
\hline Fineness modulus & 5.15 & 5.26 & 5.67 & 5.76 \\
\hline $\begin{array}{c}\text { Absorption }(\%) \\
\text { (coarse aggregate) }\end{array}$ & 10.6 & 9.6 & 10.2 & 16.1 \\
\hline $\begin{array}{l}\text { Absorption }(\%) \\
\text { (fine aggregate) }\end{array}$ & 6.2 & 5.0 & 8.0 & 8.4 \\
\hline $\begin{array}{c}\% \text { finer than } \\
\# 200 \text { sieve }\end{array}$ & 1.7 & 1.7 & 2.1 & 2.2 \\
\hline $\begin{array}{l}\text { Bulk specific gravity } \\
\text { (course aggregate) }\end{array}$ & 1.74 & 1.55 & 1.64 & 1.46 \\
\hline $\begin{array}{l}\text { Bulk specific gravity } \\
\text { (fine aggregate) }\end{array}$ & 2.12 & 1.83 & 1.85 & 1.88 \\
\hline $\begin{array}{l}\text { Rodded density } \\
\qquad\left(\mathrm{g} / \mathrm{cm}^{3}\right)\end{array}$ & 0.96 & 0.84 & 0.83 & 0.81 \\
\hline $\begin{array}{l}\text { Loose density } \\
\qquad\left(\mathrm{g} / \mathrm{cm}^{3}\right)\end{array}$ & 0.85 & 0.76 & 0.77 & 0.72 \\
\hline $\begin{array}{l}\text { Clay lumps }(\%) \\
(\%)(\# 4-\# 16)\end{array}$ & 0.5 & 1.6 & NA & 1.3 \\
\hline $\begin{array}{l}\text { Clay lumps }(\%) \\
(3 / 8-\# 4)\end{array}$ & 0.6 & 1.4 & 1.6 & 1.6 \\
\hline $\begin{array}{l}\text { Clay lumps } \\
(\%)(3 / 4-3 / 8)\end{array}$ & 1.1 & 1.5 & 1.7 & 1.5 \\
\hline
\end{tabular}




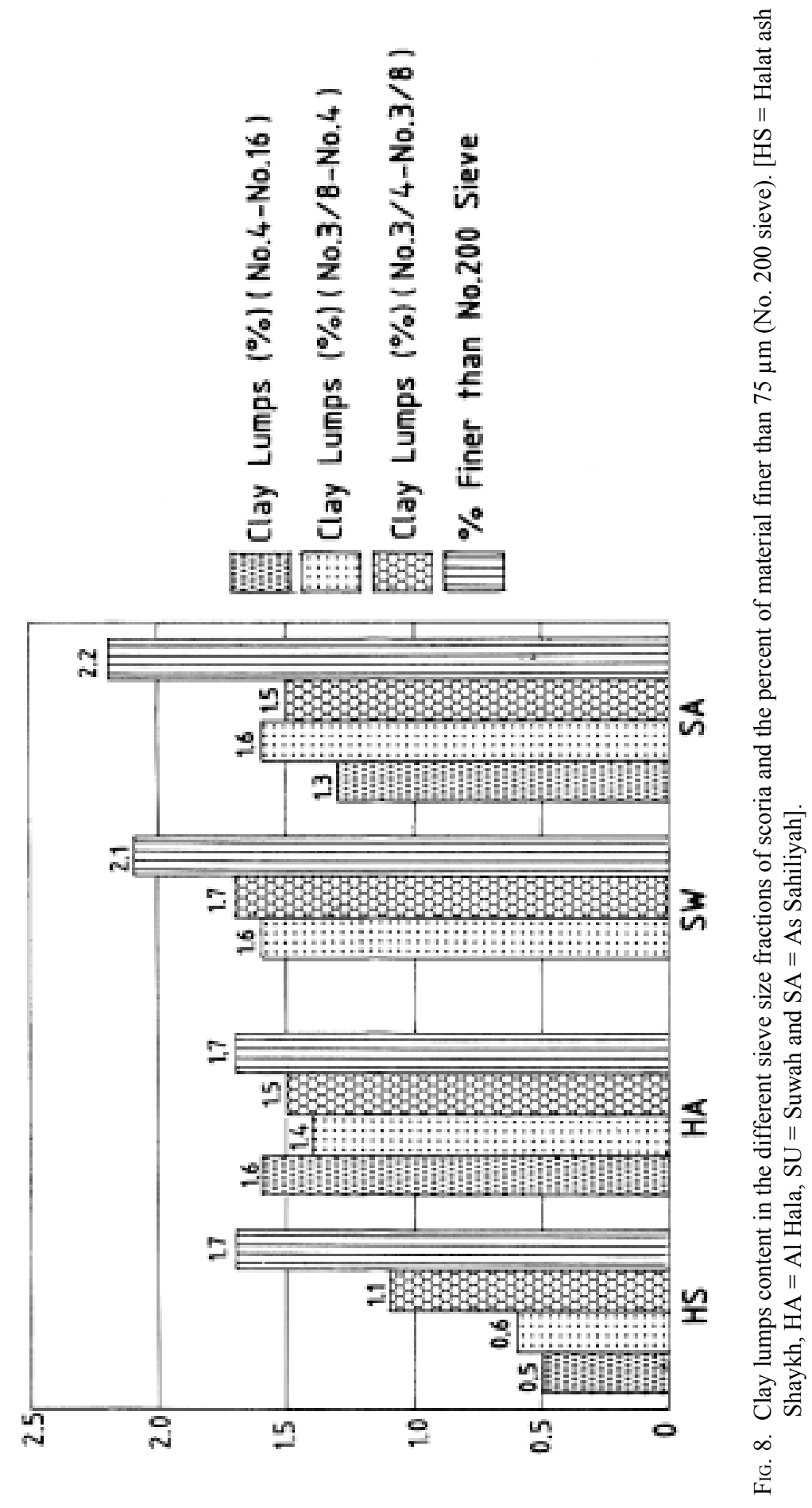




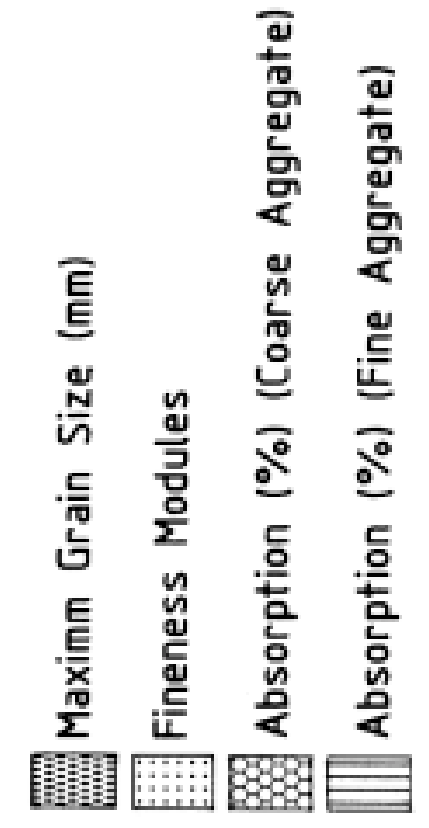

(1)

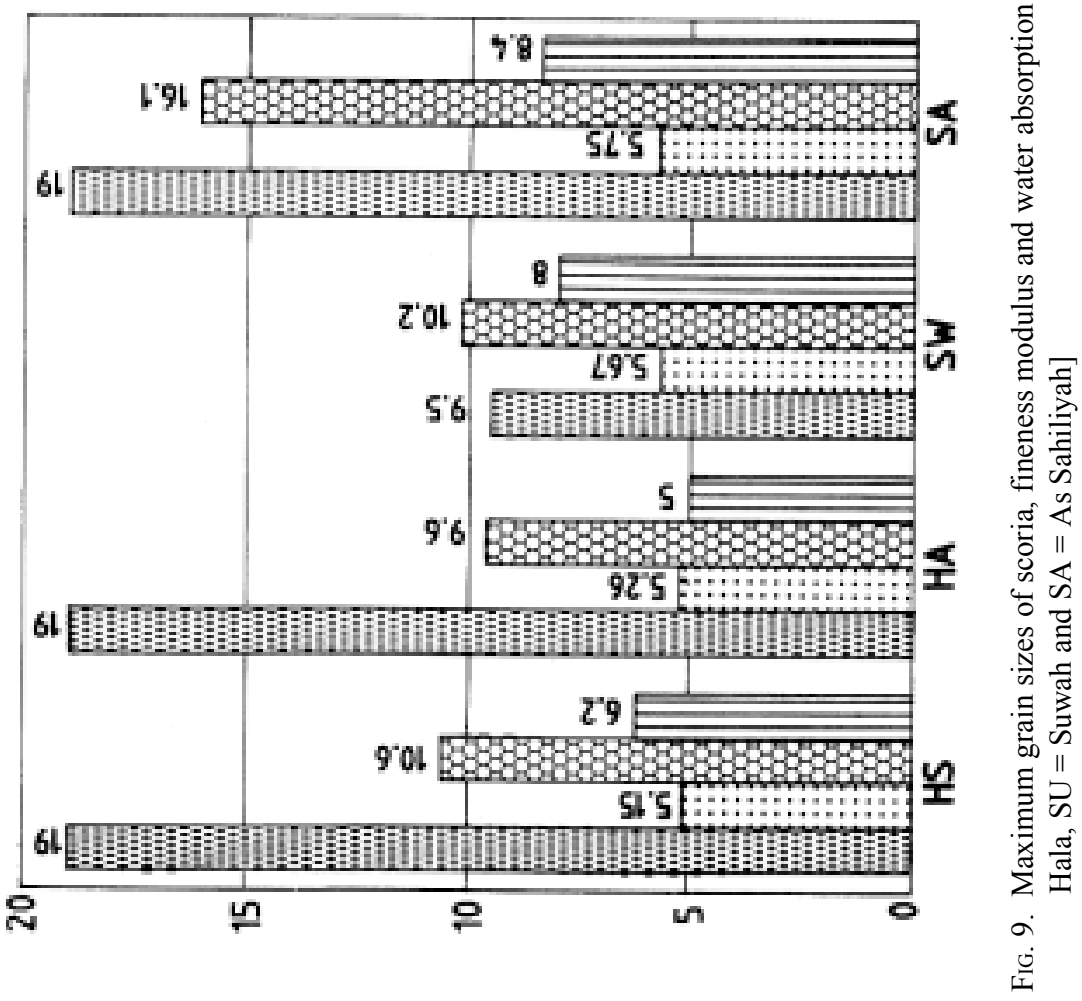




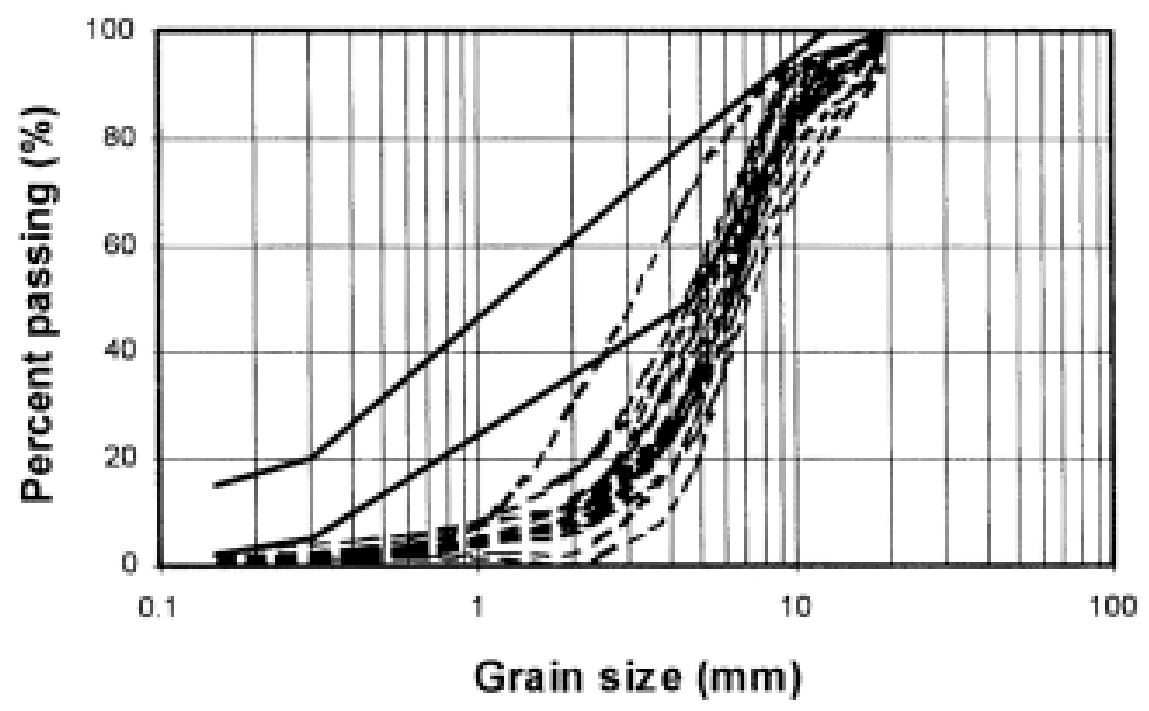

FIG. 10. Grain sizes distribution of scoria from the four cones (dashed lines). The solid lines show the lower and upper distribution limits set by ASTM.

\section{Industrial Applications}

The scoria may have several industrial applications. It can be used as lightweight aggregate, as an additive to the Portland cement to improve its properties, or as heat insulating material. Other industrial applications may include its utilization as abrasive material, as sound insulator, as filler in paint, plastics and drilling mud, or in the manufacture of rock wool.

\section{Utilization of scoria as light weight aggregate}

Lightweight aggregate is used to provide material for lightweight structural concrete and precast concrete units as well as for building blocks. The particles of the studied scoria deposits are subrounded to angular and have rough to very rough surfaces, which are expected to produce harsh mixes. Three concrete mix designs were prepared to test the scoria as structural concrete (Table 2) according to the recommendations of CIC.

The silica fume is a pozzolanic material consisting of $>90 \%$ silicon dioxide. It was added to increase the strength of the concrete and it also decreases its permeability. The Cico FLUID FG admixture is used to optimize the cement content to get the desired strength and significantly reduces water while keeping the same workability. Concrete cubes $(150 \times 150 \mathrm{~mm})$ were prepared using the different mixes and tested for their uniaxial compressive strength after 28 days of curing time. The materials from Jabal Halat ash Shaykh were obtained from the crusher and conformed to the required specifications. Those from Jabal Al 

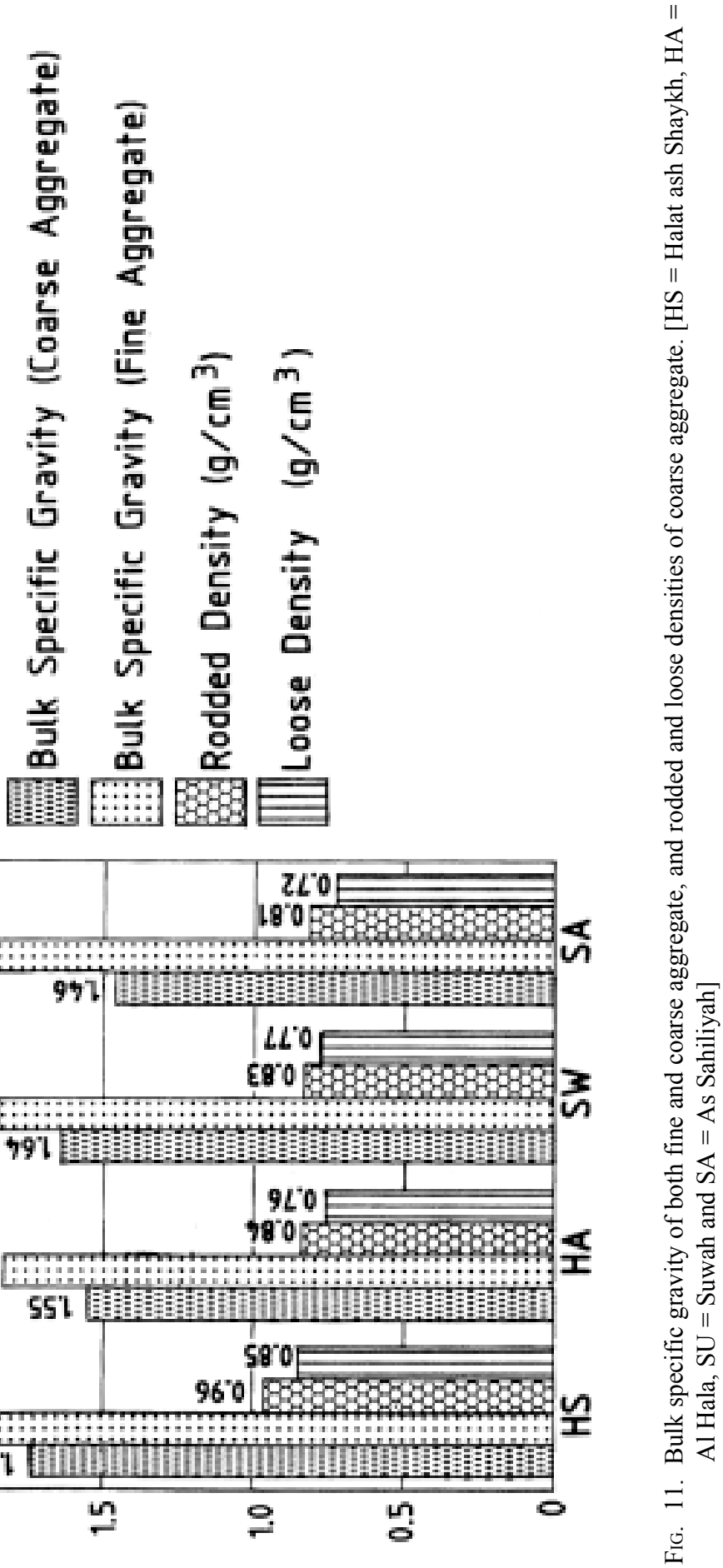
Hala were natural and used without any processing according to the specifications of Mix 3 which was found to be the most suitable. The results are given in Table 3.

$\mathrm{T}_{\mathrm{ABLE}}$ 2. Concrete mix design (amount of material to make one cubic meter of concrete) according to CIC recommendations.

\begin{tabular}{|c|c|c|c|c|c|c|}
\hline $\begin{array}{c}\text { Mix } \\
\text { design }\end{array}$ & $\begin{array}{c}\text { Water } \\
(\text { lit })\end{array}$ & $\begin{array}{c}\text { Cement } \\
(\mathrm{kg})\end{array}$ & $\begin{array}{c}\text { Coarse } \\
\text { aggregate } \\
(\mathrm{kg})\end{array}$ & $\begin{array}{c}\text { Fine } \\
\text { aggregate } \\
(\mathrm{kg})\end{array}$ & $\begin{array}{c}\text { Silica } \\
\text { fume } \\
(\mathrm{kg})\end{array}$ & $\begin{array}{c}\text { Cico fluid } \\
\text { FG } \\
\text { admixture } \\
(\text { lit })\end{array}$ \\
\hline Mix 1 & 315 & 350 & 500 & 800 & 35 & 3.5 \\
\hline Mix 2 & 340 & 400 & 500 & 750 & 40 & 4.0 \\
\hline Mix 3 & 350 & 450 & 500 & 750 & 45 & 4.5 \\
\hline
\end{tabular}

TABLE 3. Uniaxial compressive strength of the tested concrete samples.

\begin{tabular}{|l|c|c|c|c|}
\hline Location & $\begin{array}{c}\text { Mix } \\
\text { design }\end{array}$ & $\begin{array}{c}\text { Average density } \\
\left(\mathrm{kg} / \mathrm{m}^{3}\right)\end{array}$ & $\begin{array}{c}\text { Average uniaxial } \\
\text { compressive } \\
\text { strength } \\
(\mathrm{MPa})\end{array}$ & $\begin{array}{c}\text { Required uniaxial compressive } \\
\text { strength for structural } \\
\text { (MPa) }\end{array}$ \\
\hline $\begin{array}{l}\text { Jabal Halat } \\
\text { ash Shaykh }\end{array}$ & Mix 1 & 1740 & 35.8 & 28 \\
\cline { 2 - 5 } & Mix 2 & 1629 & 37.2 & 21 \\
\cline { 2 - 5 } & Mix 3 & 1706 & 38.2 & 28 \\
\hline $\begin{array}{l}\text { Jabal Al } \\
\text { Hala }\end{array}$ & Mix 3 & 1550 & 14.0 & 17 \\
\hline
\end{tabular}

The results of the uniaxial compressive strength of Jabal Halat ash Shaykh concrete mixes were acceptable for light weight structural concrete according to ASTM specifications C 330. However, the results of Jabal Al Hala mix were not acceptable not because of the bad quality of the material but because the material was used without processing and the grading did not conform to the recommended specification. This was the reason for not repeating these experiments on the material collected from Jabal as Sahiliyah.

\section{Utilization of scoria as cement additive}

Concrete mixes containing around $20 \%$ fly ash as replacement to cement improves compressive strength, permeability and sulfate/chloride attack on con- 
crete (Hanif, 1980; Al-Amoudi, 1985). It also improves the durability performance of the reinforced concrete (KFUPM/RI, 1985). The scoria can be naturally pozzolanic material and may replace the fly ash as an additive to the Portland cement. Several procedures were followed to test the studied scoria for its suitability as a pozzolanic material.

\section{Pozzolanic activity}

The pozzolanic activity of scoria was tested according to the Italian standards where the sample is mixed with cement and water and kept for 8-15 days. The total alkalinity $\left(\mathrm{OH}^{-}\right)$and lime concentration $(\mathrm{CaO})$ are then measured. The material is considered pozzolanically active if the level of concentration falls below the lime solubility isotherm. Fig. 12 shows that all the samples collected from the four sites, except one sample from Jabal Suwah, were found to be pozzolanically active.

\section{Strength activity index with Portland cement}

The strength activity index test was performed on the scoria samples from Jabal Halat ash Shaykh. The test was conducted with some modification from the ASTM Designation C 311. Several mortar cubes $(5 \times 5 \mathrm{~mm})$ were prepared according to the mixes given in Table 4 . The cubes were then stored in moist closet for 24 hours then in saturated lime water until tested for their uniaxial compressive strengths at ages of 7 and 28 days.

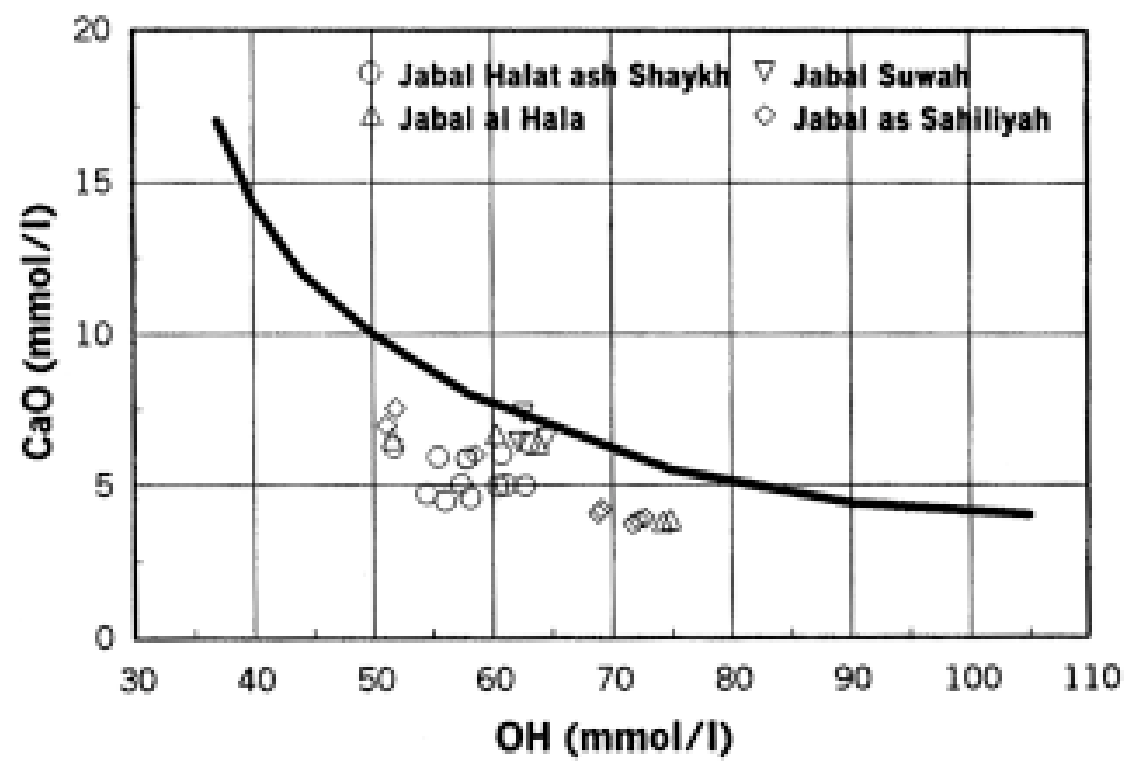

Fig. 12. Pozzolanic activity of scoria samples from the four cones. 
TABLE 4. Mixes prepared for the strength activity index with Portland cement.

\begin{tabular}{|c|c|c|c|c|}
\hline Mixes & $\begin{array}{c}\text { Ground scoria } \\
(\mathrm{g})\end{array}$ & $\begin{array}{c}\text { Portland } \\
\text { cement } \\
(\mathrm{g})\end{array}$ & $\begin{array}{c}\text { Silica sand } \\
(\mathrm{g})\end{array}$ & Water $(\mathrm{ml})$ \\
\hline Mix 1 & 0 & 500 & 1375 & 242 \\
\hline Mix 2 & 50 & 450 & 1375 & Variable* \\
\hline Mix 3 & 100 & 400 & 1375 & Variable* \\
\hline Mix 4 & 150 & 350 & 1375 & Variable* \\
\hline Mix 5 & 200 & 300 & 1375 & Variable* \\
\hline
\end{tabular}

*Water requirement is calculated as a function of the control flow.

The uniaxial compressive strength values of the tested samples are given in Table 5 and presented in Fig. 13. It is obvious that the uniaxial compressive strength is more or less the same for all the mixes even with $10 \%$ scoria. The strength values range between 28 and $38 \mathrm{MPa}$ which is much less than the $75 \%$ strength value (relative to the zero scoria content samples) at 7 days as required by ASTM Designation $\mathrm{C}$ 618. The reason for the low strength activity indices is possibly because the scoria was ground to pass sieve \#200 $(75 \mu \mathrm{m})$ while the specification requires the sample to be ground to pass sieve \#325 $(45 \mu \mathrm{m})$. This test will be repeated on material finer than $45 \mu \mathrm{m}$ for better evaluation of the results.

TABLE 5. Strength activity index with Portland cement test results.

\begin{tabular}{|c|c|c|}
\hline $\begin{array}{c}\text { Ground scoria content } \\
(\%)\end{array}$ & $\begin{array}{c}\text { Average uniaxial } \\
\text { compressive strength } \\
(\mathrm{MPa})\end{array}$ & Strength activity index \\
\hline 0 & 10.14 & - \\
\hline 10 & 3.90 & 38 \\
\hline 20 & 2.86 & 28 \\
\hline 30 & 3.06 & 36 \\
\hline 40 & 3.70 & 36 \\
\hline
\end{tabular}

\section{Effectiveness of scoria admixture in controlling alkali silica reactions}

The alkali silica reaction test covers the determination of the effectiveness of ground scoria in preventing the excessive expansion caused by the alkali silica reactions. The test was performed, with modification, according to ASTM Designation $C$ 311. Several mortar cubes $(5 \times 5 \mathrm{~mm})$ were prepared according to the mixes given in Table 6 . The cubes were then stored in a moist closet and their lengths were measured on the 1 st day and the 14 th day. 


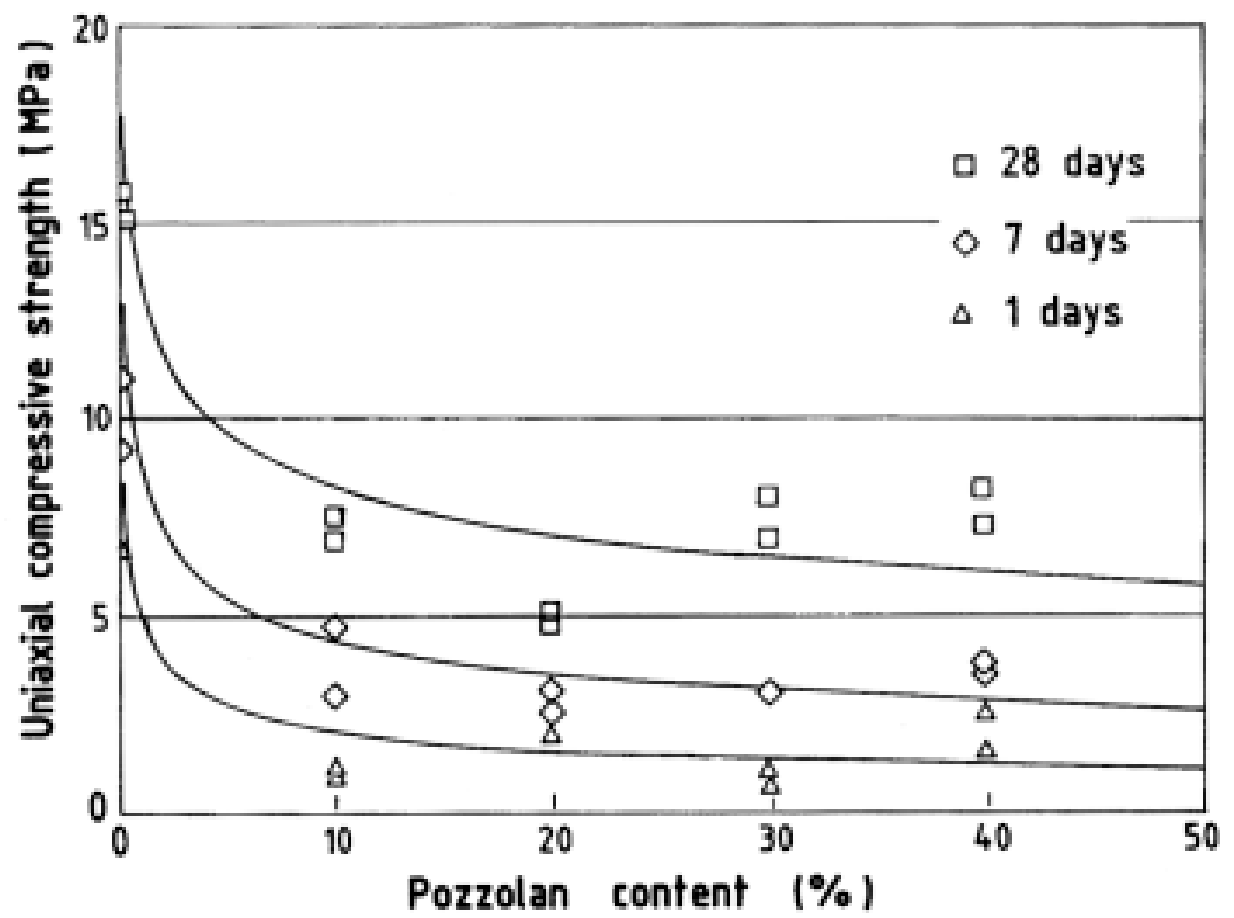

FIG. 13. Relationship between uniaxial compressive strength of the mortar cubes and scoria content of the samples prepared for strength activity test.

TABLE 6. Mixes prepared for the effectiveness of scoria in controlling alkali silica reactions.

\begin{tabular}{|l|c|c|c|c|}
\hline Mixes & $\begin{array}{c}\text { Ground scoria } \\
(\mathrm{g})\end{array}$ & $\begin{array}{c}\text { Portland } \\
\text { cement } \\
(\mathrm{g})\end{array}$ & $\begin{array}{c}\text { Silica sand } \\
(\mathrm{g})\end{array}$ & Water $(\mathrm{ml})$ \\
\hline Mix 1* & 0 & $400^{*}$ & 900 & Variable** \\
\hline Mix 2 & 40 & 360 & 900 & Variable** $^{*}$ \\
\hline Mix 3 & 80 & 320 & 900 & Variable** \\
\hline Mix 4 & 120 & 280 & 900 & Variable** \\
\hline Mix 5 & 160 & 240 & 900 & Variable** \\
\hline
\end{tabular}

\footnotetext{
*Mix 1 is a control mix and is made with low alkali cement.

**Water enough to produce a flow between 100 and $115 \%$.
}

The average expansion of the cubes on the 14th day is given in Table 7 and presented in Fig. 14. Although the dispersion is high among these curves, they 
roughly show that the increase in scoria content decreases the expansion of the mortar cubes.

TABLE 7. Effectiveness of scoria admixture in controlling alkali silica reactions test results.

\begin{tabular}{|c|c|c|}
\hline $\begin{array}{c}\text { Ground scoria content } \\
(\%)\end{array}$ & $\begin{array}{c}\text { Average expansion on } \\
\text { the 14th day } \\
(\mathrm{mm})\end{array}$ & $\begin{array}{c}\text { Reduction in expansion } \\
(\%)\end{array}$ \\
\hline $0^{*}$ & 0.179 & - \\
\hline 10 & 0.224 & 125 \\
\hline 20 & 0.240 & 85 \\
\hline 30 & 0.153 & 110 \\
\hline 40 & 0.197 & 134 \\
\hline
\end{tabular}

*Control mix.

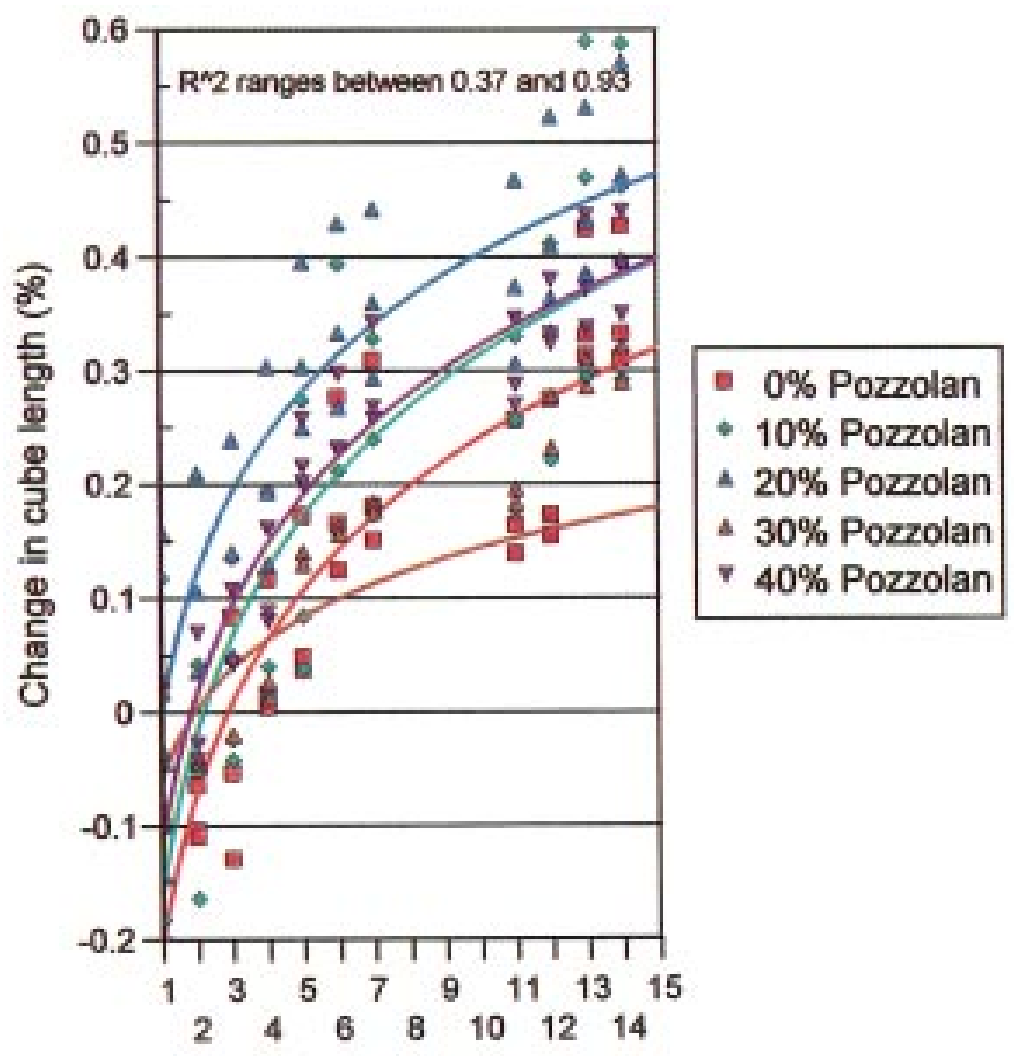

FIG. 14. Relationship between change in mortar cube length and scoria content as a measure of the effectiveness of scoria in controlling alkali silica reactions. 
ASTM Designation C 618 requires that, for the effectiveness in controlling alkali silica reactions, the reduction in expansion (the ratio between the expansion of the test mix and that of the control mix) on the 14th day, should have a maximum value of $100 \%$. It is obvious that Mix 3 with $30 \%$ scoria content satisfies this requirement. However, the scoria used was ground to pass sieve \#200 $(75 \mu \mathrm{m})$ while the specification requires the sample to be ground to pass sieve \#325 (45 $\mu \mathrm{m})$. This might have also affected the test results and other mixes could have passed the required reduction ratio. This test will be repeated on material finer than $45 \mu \mathrm{m}$ for better evaluation of the results.

\section{Utilization of scoria as heat insulating material}

The low density and the good heat insulation properties of the scoria make it highly resistant to heat flow and thus can be used in the manufacturing of heat insulating building blocks. Pumice concrete, which is the acid pyroclastic equivalent of the scoria, is six times as effective heat insulator as ordinary concrete (Bates, 1960 and Lefond, 1983). Discs were cut from concrete cylinders prepared according to the three mix designs given in Table 2. The discs were 17 to $22 \mathrm{~mm}$ in thickness and $150 \mathrm{~mm}$ in diameter. The discs were tested in Lees' apparatus (Fig. 15) which is used for measuring the thermal conductivity of bad conductors. The heat conductivity value of the tested concrete discs is function of the rate of flow of heat of the brass disc, the cross sectional area of the sample and the temperature gradient between the upper brass disc and the lower brass disc.

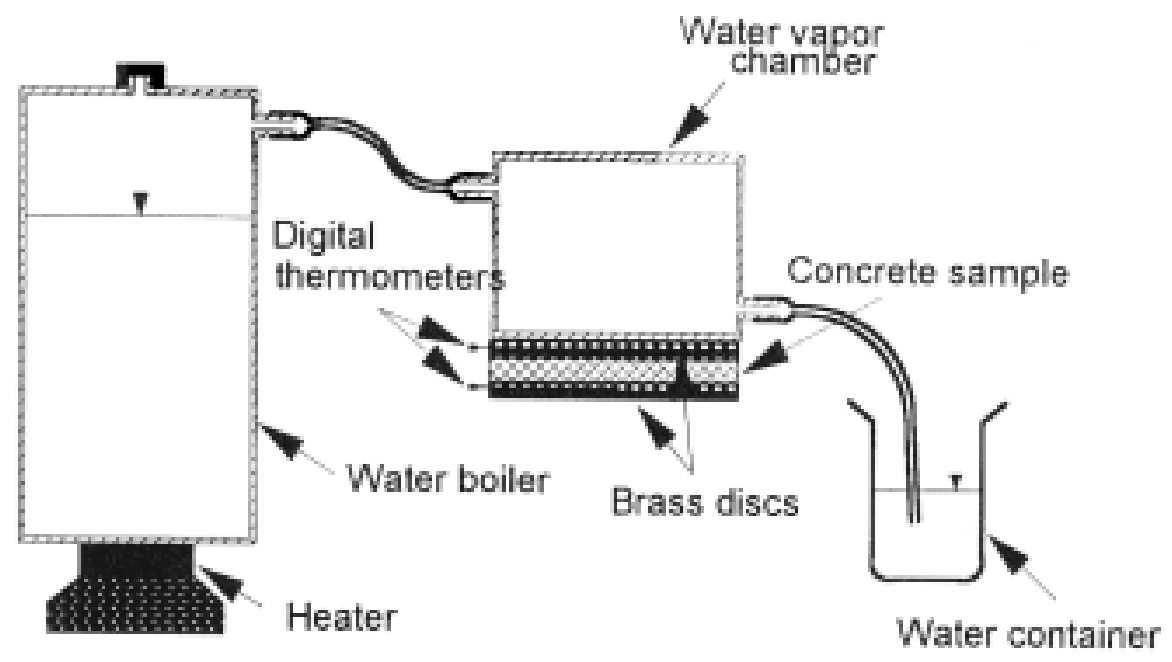

FIG. 15. Lees' apparatus for measuring the thermal conductivity of bad conductors. 
The preliminary results (Table 8) indicate that the heat insulation results for all the mixes satisfy the ASTM Designation C 332 requirement for insulating concrete with values of heat conductivity less than 0.43 W.K-1.m-1. Mix 3, on the other hand, shows better preliminary results than the other mixes.

TABLE 8. Heat conductivity of the concrete mixes

\begin{tabular}{|c|c|}
\hline $\begin{array}{c}\text { Concrete mix } \\
(\text { see Table 2) }\end{array}$ & $\begin{array}{c}\text { Heat conductivity } \\
\text { W.K } \mathrm{K}^{-1} \cdot \mathrm{m}^{-1}\end{array}$ \\
\hline Mix 1 & 0.20 \\
\hline Mix 2 & 0.18 \\
\hline Mix 3 & 0.17 \\
\hline
\end{tabular}

\section{Conclusions and Recommendations}

The geomorphological studies of the volcanic cones may be used as an exploration tool for locating scoria deposits. The studied scoria deposits show similarity in their geological occurrence, their petrography, their material description and their physical properties. The studied scoria was found to be suitable in manufacturing light weight concrete, as an additive to the Portland cement for being pozzolanically active and in the production of heat insulating building blocks.

Further investigations on the strength activity index and alkali silica are recommended to be done on finer material in order to better evaluate the results.

\section{Acknowledgement}

The authors wish to extend their gratitude to King Abdulaziz University for their financial support of Project No. 417/201 and the Faculty of Earth Sciences for making their laboratories and field facilities available for the research team. The authors are also grateful to CLC Company for giving the research team access to their site and permitting them to use their facilities and equipment.

\section{References}

Al-Amoudi, O. (1985) Studies on the evaluation of permeability and corrosion resisting characteristics on Portland pozzolan concrete: Unpublished Thesis, King Fahd University of Petroleum and Minerals, $53 \mathrm{p}$.

ASTM (1990) Standard test method for clay lumps and friable particles in aggregates: Amer. Soc. Test. Mater., Designation C 142.

ASTM (1994) Standard test methods for sampling and testing fly ash or natural pozzolans for use as a mineral admixture in Portland cement concrete: Amer. Soc. Test. Mater., Designation C 311 . 
ASTM (1989) Standard specification for lightweight aggregates for structural concrete: Amer. Soc. Test. Mater., Designation C 330.

ASTM (1994) Standard specifications for lightweight aggregates for concrete masonry units: Amer. Soc. Test. Mater., Designation C331.

ASTM (1987) Standard specification for lightweight aggregates for insulating concrete: Amer. Soc. Test. Mater., Designation C 332.

ASTM (1997) Standard specification for coal fly ash and raw or calcined natural pozzolan for use as a mineral admixture in concrete: Amer. Soc. Test. Mater., Designation C 618.

Bates, R. L. (1960) Geology of the industrial rocks and minerals. Harper and Brothers, Publishers, New York, N.Y.

Benedetto, A. and Baudet, G. (1975) Recommendations for beneficiation studies of industrial minerals in the Kingdom of Saudi Arabia. BRGM Open-File Report. 75-JED-27. 141 p., 1 table.

Brown, G. F. (1972) Tectonic map of the Arabian Peninsula. Saudi Arabian Directory General for Mineral Resources, Arabian Peninsula Map, AP-2 (1:4,000,000).

Brown, G. F., Jackson, R. O., Bogue, R. G. and Elberg, E. L. Jr. (1963a) Geologic map of the northwestern Hijaz quadrangle, Kingdom of Saudi Arabia, U.S. Geological Survey Miscellaneous Geologic Investigation Map I-204A, scale 1:500,000.

Brown, G. F., Jackson, R. O., Bogue, R. G. and Maclean, W. H. (1963b) Geologic map of the southern Hijaz quadrangle, Kingdom of Saudi Arabia, U.S. Geological Survey Miscellaneous Geologic Investigation Map I-210A, scale 1:500,000.

Camp, V. E. and Roobol, M. J. (1987) Geologic map of the Cenozoic lava field of Harrat Rahat, Kingdom of Saudi Arabia. Saudi Arabian Deputy Ministry for Mineral Resources OpenFile Report DGMR-OF-07-9: 91p.

Camp, V. E. and Roobol, M. J. (1989) The Arabian continental alkali basalt province: Part II. Evolution of the Harrat Rahat, Kingdom of Saudi Arabia. Geological Society of America Bulletin, 101: 71-95.

Hanif, M. (1980) Performance of pozzolan cement concrete in a high chloride-sulfate environment: Unpublished Thesis, King Fahd University of Petroleum and Minerals, 63 p.

KFUPM/RI (1985) An investigation on the addition of pozzolans to improve the durability performance of concrete in the Eastern Province: The Research Institute, KFUPM Report, 35p.

Laurent, D. and Al Nakhebi, Z. A. (1979) Reconnaissance for pozzolan in the pyroclastic cores of the Harrats. BRGM Technical Record 79-JED-18, 60p.

Laurent, D. and Chevrel, S. (1980) Prospecting for pozzolan on Harrat Lunayyir. BRGM Open File Report JED-OR-80-13: 47p.

Laurent, D., Principal author and coordinator, Alsac, C.; Arab, N.; Berthiaux, A.; Chiron, J.; Lemiere, B.; Marteau, P.; Sheldon, R. P.; Thibaut, P.; Villalard, P., Authors With the collaboration of: Al-Dawawsi, R.; Al Nakhebi, Z.; Al Owedi, K.; Damanhori, N.; Goyallon, J.; Hazza, A.; Khogandi, M. and Rancon, J. (1993) Kingdom of Saudi Arabia Atlas, Atlas of Industrial Minerals. Saudi Arabian Directorate General of Mineral Resources (Jeddah), in cooperation with the Bureau de Recherches Geologiques et Minieres (BRGM), 130 p., 18 color figs., 16 color maps, bibliography, index.

Lefond, S. J. (1983) Industrial Rocks and Minerals, fifth edition. A.I.M.M. \& Petr. Eng. Inc., New York, N.Y.

Odent, B. and Roger, J. (1980) Prospecting for pozzolan in the Al-Birk region (southwestern province). BRGM Open-File Report JED-OR-80-15: 28p.

Roobol, M. J., Simsim, M., Tayeb, O. and Abdul-Hafaz, K. (1998a) Basalt as an industrial rock - 1. Al Madinah area: quarry sites for Al Madinah Al Munawwarah: Saudi Arabian Deputy Ministry for Mineral Resources Technical Report BRGM-TR-98-1: 84p. 
Roobol, M. J., Abdul-Hafaz, K., Simsim, M. and Tayeb, O. (1998b) Basalt as an industrial rock - 2. Central Harrat Rahat: quarry sites for Jeddah and Makkah al Mukarramah: Saudi Arabian Deputy Ministry for Mineral Resources Technical Report BRGM-TR-98-7: 50p.

Roobol, M. J., Simsim, M., Abdul-Hafaz, K. and Tayeb, O. (1999) Basalt as an industrial rock - 3. Harrat Kishb: quarry sites for At Ta'if, Ar Riyadh and Ad Dammam: Saudi Arabian Deputy Ministry for Mineral Resources Technical Report BRGM-TR-98-13: 117p.

Watts, Griffis and McOuat Limited (1992a) Evaluation and studies project: Extent, status and adequacy of mineral exploration in the Phanerozoic rocks. Saudi Arabian Directorate General of Mineral Resources Confidential Report WGM-CR-11-15: $275 \mathrm{p}$.

Watts, Griffis and McOuat Limited (1992b) Evaluation and studies project: Recommendations for further mineral exploration in the Phanerozoic rocks: Saudi Arabian Directorate General of Mineral Resources Confidential Report WGM-CR-11-16: 142 


\title{
التقيـيم الاقتصـادي و الهنــدسي للترسبات الفتاتيـة البركانيـة في الجزء الأوسط من حقل اللابا الحديث في حرة رهط
}

\author{
محمد رشاد مفتي ، عبد الله سبتان ، عمر رشيد المهدي و و وليم مكرم شحاته

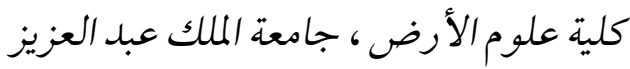 \\ جلدة - المملكة العربية السعودية
}

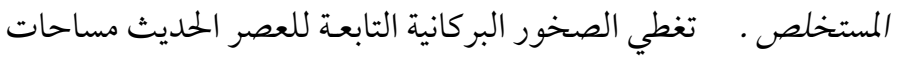

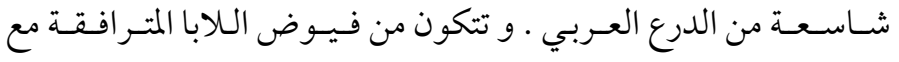

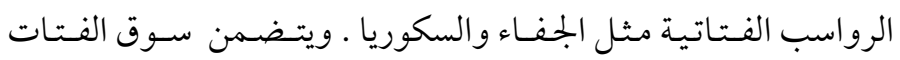

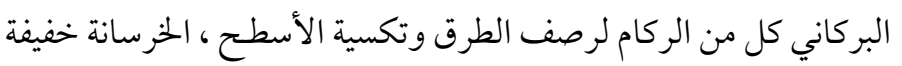

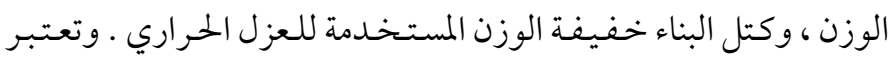

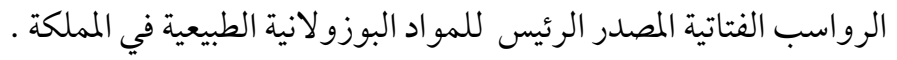

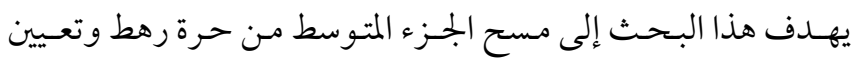

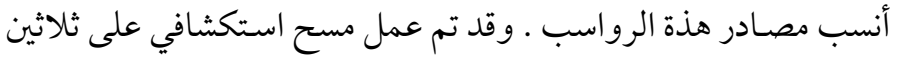

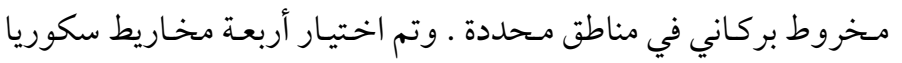

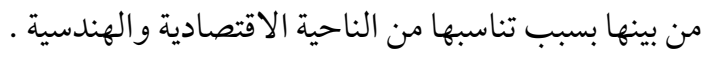

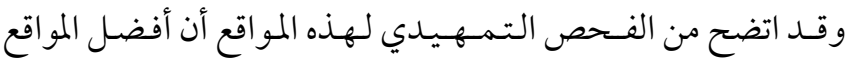

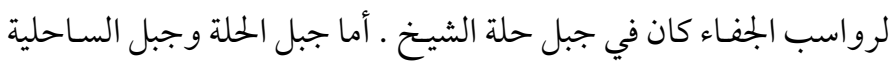

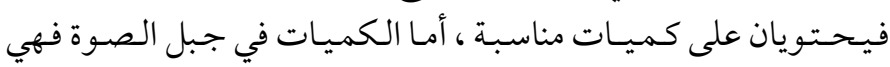

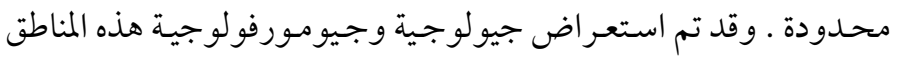

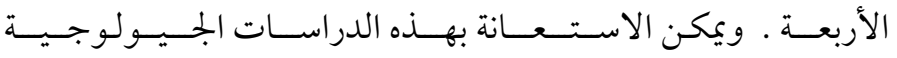

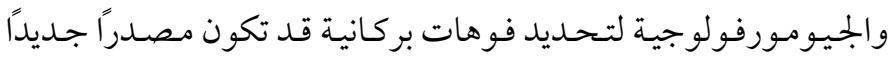

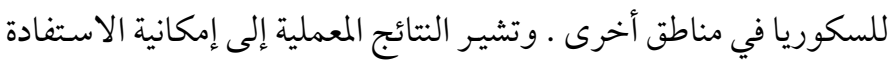

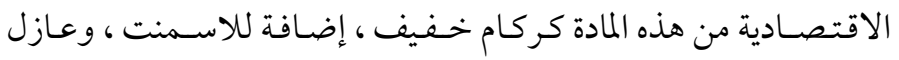

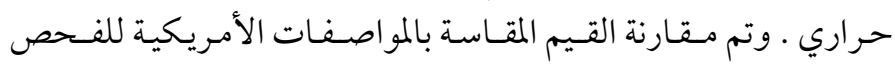

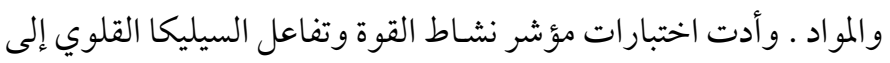




$$
\begin{aligned}
& \text { نتائج غير مشجعـة بسبب مشـاكل تقنيـة ، كما سيتم إعـادة الاختبـارات }
\end{aligned}
$$

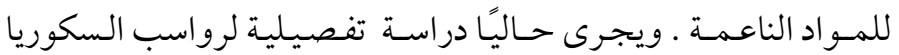

$$
\begin{aligned}
& \text { والخرسا نة المكونة منها وذلك من النواحي الاقتصادية والهندسية . }
\end{aligned}
$$

